\title{
CHRONIC EFFECT ANALYSIS OF MERCURY EXPOSURE ON COMMUNITIES AROUND SMALL SCALE GOLD MINING IN INDONESIA USING HUMAN BIOMONITORING (HBM) METHOD
}

\author{
Haryo Mubiarto ${ }^{1}$, Herto Dwi Ariesyady ${ }^{2 *}$, Siska Widya Dewi Kusumah ${ }^{2}$, and Juli Soemirat ${ }^{2}$ \\ ${ }^{1}$ Master's Program of Environmental Engineering, Institut Teknologi Bandung, Jl. Ganesha 10 Bandung 40132, Indonesia \\ ${ }^{2}$ Environmental Management Technology Research Group, Faculty of Civil and Environmental Engineering, Institut Teknologi \\ Bandung, Jl. Ganesha 10 Bandung 40132, Indonesia
}

\begin{abstract}
In general, small-scale gold mining activities that are spread throughout Indonesia practicing amalgamation technique. The amalgamation process in the mining activities can result in environmental degradation due to tailing waste containing mercury that are discharged into the environment and will distributed and bioaccumulated through food chain. Mercury exposure to human can give a chronic effect. Measuring mercury concentration in biomarkers such as nail and hair is a method to indicate the mercury poisoning level. Therefore, the purpose of this study was to analyze mercury concentrations in nail and hair as chronic exposure biomarkers. Besides, we also conducted Human Biomonitoring (HBM) analysis to assess mercury intoxication in the communities. Moreover, we analyzed mercury concentrations in water, rice, fish, and food crops samples to understand their association with mercury concentrations in nail and hair through a Provisional Tolerable Weekly Intake (PTWI) analysis. This research was conducted in 4 districts in Indonesia which has a significant number of small-scale gold mining activities. The results showed that the maximum concentration of $\mathrm{T}-\mathrm{Hg}$ in the nail and hair of the workers was $58.48 \mu \mathrm{g} / \mathrm{g}$ and $55.97 \mu \mathrm{g} / \mathrm{g}$, respectively. Based on HBM analysis, in several districts, more than $60 \%$ of the workers has been intoxicated by mercury. Meanwhile, Average Daily Intake (ADI) and PTWI were significantly correlated with concentration mercury in the nail and hair. Mercury concentrations in worker's hair was significantly correlated with working experience. We identified that the age and residence duration were the major predictor of concentration mercury in nail and hair, respectively.
\end{abstract}

\section{INTRODUCTION}

Amalgamation is a common practice that used by small-scale gold miner throughout Indonesia. This technique use mercury to bind gold from sand or rocks and produce tailing waste with high mercury content. This tailing wastes then discharged into the river and cause environmental quality degradation [1]. In addition, mercury in tailing wastes may be distributed to the surrounding area, contaminating soil surface and ground water, absorbed by plants, and bioaccumulate in the food chain [2].

The miners and society around the mining site pose higher risk of getting chronic mercury poisoning from direct contact with mercury of from other routes, such as eating mercury-contaminated food/water (oral) and inhalation. Measurement of mercury concentration in human biomarker, such as nail and hair, can be used as early detection of mercury poisoning. According to Bellinger et al., (2016), total mercury (T-Hg) concentration in the hair may indicate chronic cumulative mercury exposure up to several months, depend on the length of the hair samples [3]. According to He (2011), nails samples have the same reliability as hair samples to be used as biomarkers for mercury exposure [4].

The risk of mercury poisoning is high when a person exceeds maximum daily intake for mercury. In Bhupandar and Mukherjee (2011), to know whether mercury intake rate is still within the tolerance limits (safe levels for human) can be measured as PTWI (Provisional Tolerable Weekly Intake) on a daily or weekly basis according to the Joint Expert Committee on Food Additives (JECFA). Therefore, any person with high weekly intake of mercury exceeding tolerance limit (PTWI) will pose higher risk and more likely to show various sign and symptom of mercury poisoning which can be detected by Human Biomonitoring method (HBM) [5]. In chemical risk management, HBM have been widely used as one of risk assessment tool for chemical exposure to human. The HBM calculation results can also indicate chemical poisoning, such as mercury poisoning [6]. Therefore, the Human Biomonitoring Method (HBM)

*Corresponding author: herto@ftsl.itb.ac.id 
was also calculated in this research to analyze the chronic adverse effects of people exposed to mercury from smallscale gold mining activities.

\section{MATERIALS AND METHOD}

\subsection{Sampling Area}

The research was carried out in 4 regencies in Indonesia, namely WG, MR, DH, and KB Regency as the representative of small-scale gold mining area that still use mercury in the amalgamation process (Fig. 1). The study was conducted from July to September 2018. In WG Regency which located in Central Java Province, the miners use "gelundung" process to crush the ore before the amalgamation process. In the second location, the MR Regency in Jambi Province, the miners use an excavator to dig the rock or sand from the river, then traditional panning was used to concentrate the gold from alluvial materials. The third and fourth site (DH Regency in West Sumatera Province and KB Regency in Central Kalimantan Province), the miners also use "gelundung" to crush the ore before amalgamation process. In KB regency, a few miners may also use chemicals, such as cyanide to assist the amalgamation process.

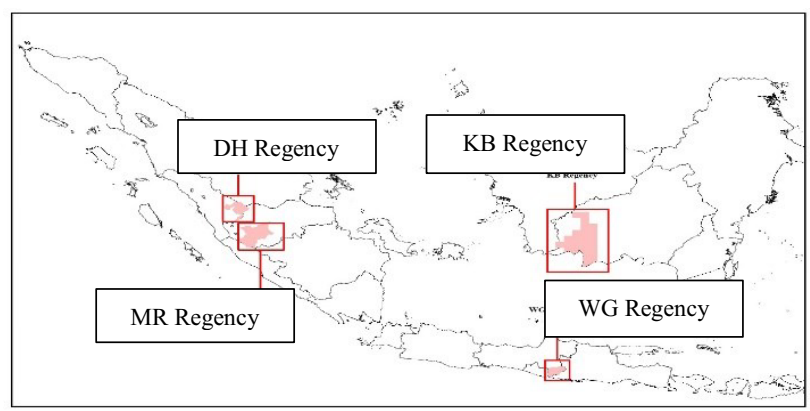

Fig. 1. Study location of this research in four regencies in Indonesia (Source: BIG Indonesia, 2019)

\subsection{Sampling Methods}

In this study, samples were collected from consumable goods and human biomarker (hair and nail) as seen on Table 1. Rice, fish, groceries and drinking water was directly obtained from local land and river near the ASGM site that consumed directly by the communities. Number of samples depends on local variants and availability of consumable goods.

Table 1. Number of samples obtained from each regency

\begin{tabular}{cccccc}
\hline Regency & Respondent & Rice & $\begin{array}{c}\text { Drinking } \\
\text { Water }\end{array}$ & Fish & Groceries \\
\hline WG & 50 & 12 & 10 & 2 & 4 \\
\hline MR & 47 & 9 & 10 & 4 & 11 \\
\hline DH & 56 & 8 & 8 & 5 & 11 \\
\hline KB & 45 & 5 & 3 & 8 & 4 \\
\hline Total & 198 & 34 & 31 & 19 & 30 \\
\hline
\end{tabular}

Adult respondents (Age $>20$ years old) in both genders were chosen in every area by randomized purposive sampling. Respondents may also consist of non-miner since no criteria restricting certain profession. Ethical clearance and informed consent had been given to all respondents prior taking hair and nail samples to obtain their permission. The nails and hair samples were collected from each respondent using nail clipper and scissors. The minimum length of the nails was $1 \mathrm{~mm}$ [7]. The minimum amount of hair samples were 20 strands of hair [8]. Samples was well preserved in $4^{0} \mathrm{C}$ using cold storage when transported to the lab.

\subsection{Chemical Analysis}

The samples that had been collected at the sampling site were extracted based on Mercury Analysis Manual Method [8] and national standard for consumption water samples extraction (SNI 6989.78:2011) [9]. Concentration of mercury on extracted samples was measured using the ICP-MS (Inductively Coupled Plasma-Mass Spectrometry) method. The mercury concentration in hair and nail samples were compared with the safe limit from WHO standard. While, the mercury concentration in consumable goods were compared with safe limit from national standard (SNI).

Furthermore, the concentration of mercury in consumable goods become the basis for PTWI calculation combined with additional information about respondent's consumption pattern. Provisional Tolerable Weekly Intake (PTWI) is a safe limit level of heavy metal that may chronically ingested via weekly food consumption. Based on SNI 7387: 2009, the PTWI value for total mercury is $5 \mu \mathrm{g} / \mathrm{kg}$-week [11]

\subsection{Human Biomonitoring}

Mercury intoxication status for all 198 subjects was determined using HBM (Human Biomonitoring) analysis. Several medical tests were done by the respondents to obtain the medical score, such as anamnesis, tremor test, ataxia test, dysdiadochokinesia test, and neuropsychological test [10]. Mercury intoxication status is obtained by comparing the medical score and mercury concentration in each respondent's hair and nail samples. Respondents with high medical score and mercury concentration found in hair and nail samples will more likely to be considered as having mercury intoxication.

\subsection{Data Analysis}

Obtained data was analyzed using statistical correlation and regression to know the association between Provisional Tolerable Weekly Intake (PTWI) and mercury concentrations in respondent's nails and hair, the association between mercury concentrations in nails and hair with personal attributes, and the association between mercury intoxication status (from HBM) and mercury concentration in people's nails and hair.

\section{RESULTS AND DISCUSSION}

\subsection{Mercury Concentration in Biomarkers}

Table 2 shows mercury concentration in nail and hair sample of all respondents. In all districts, mercury concentration on most of nail samples were exceed the 
safe limit value from WHO quality standard $(1.6 \mu \mathrm{g} / \mathrm{g})$ [12]. Only nail samples from respondents in DH Regency that meets the WHO threshold value. The average mercury concentration was found very high in WG Regency, which was $9.95 \mu \mathrm{g} / \mathrm{g}$, with a minimum mercury concentration of $1.1 \mu \mathrm{g} / \mathrm{g}$ and a maximum concentration of $30.93 \mu \mathrm{g} / \mathrm{g}$. While the lowest average mercury concentration was found in DH Regency, which was 1.28 $\mu \mathrm{g} / \mathrm{g}$, with a minimum mercury concentration was below Limit of Detection $(<\mathrm{LOD})$ that is $0.00004 \mu \mathrm{g} / \mathrm{g}$ and a maximum concentration of $16.95 \mu \mathrm{g} / \mathrm{g}$.

The average mercury concentration in hair also exceed the WHO UNEP standard of $2 \mu \mathrm{g} / \mathrm{g}$ [13] in all regencies except MR Regency. The highest average mercury concentration in hair was found in KB Regency with a concentration value of $4.76 \mu \mathrm{g} / \mathrm{g}$.
The minimum concentration in this area was below Limit of Detection. ( $<$ LOD) and maximum concentration was $20.83 \mu \mathrm{g} / \mathrm{g}$. While the lowest average mercury concentration in hair was found in MR Regency, which was $1.35 \mu \mathrm{g} / \mathrm{g}$ with a minimum concentration of $<\mathrm{LOD}$ and a maximum concentration of $9.68 \mu \mathrm{g} / \mathrm{g}$.

The highest average mercury concentration in hair was found in DH Regency with a concentration of 4.21 $\mu \mathrm{g} / \mathrm{g}$. The minimum concentration in this area was 0.1 $\mu \mathrm{g} / \mathrm{g}$ and a maximum concentration of $37.04 \mu \mathrm{g} / \mathrm{g}$. While the lowest average mercury concentration in hair was found in WG Regency, which was $0.9 \mu \mathrm{g} / \mathrm{g}$ with a minimum concentration of $0.42 \mu \mathrm{g} / \mathrm{g}$ and a maximum concentration of $2.31 \mu \mathrm{g} / \mathrm{g}$.

Table 2. Mercury concentrations in biomarkers (hair and nail samples) in each regency

\begin{tabular}{|c|c|c|c|c|c|}
\hline \multirow{2}{*}{ Biomarker } & \multirow{2}{*}{ Regency } & \multicolumn{4}{|c|}{ Worker } \\
\hline & & $\mathrm{n}$ & $\operatorname{Min}(\mu \mathrm{g} / \mathrm{g})$ & $\operatorname{Max}(\mu \mathrm{g} / \mathrm{g})$ & $\operatorname{Mean} \pm \mathrm{SD}(\mu \mathrm{g} / \mathrm{g})$ \\
\hline \multirow{4}{*}{ Nail } & WG & 35 & 1.1 & 30.93 & $9.95 \pm 7.55$ \\
\hline & MR & 34 & 0.83 & 13.51 & $4.77 \pm 3.49$ \\
\hline & $\mathrm{DH}$ & 30 & $<\mathrm{LOD}$ & 16.95 & $1.28 \pm 3.26$ \\
\hline & KB & 36 & 0.2 & 58.48 & $3.75 \pm 9.93$ \\
\hline \multirow{4}{*}{ Hair } & WG & 35 & 0.51 & 16.74 & $2.35 \pm 2.65$ \\
\hline & MR & 34 & $<$ LOD & 9.68 & $1.35 \pm 2.07$ \\
\hline & DH & 30 & 0.25 & 55.97 & $4.26 \pm 10.08$ \\
\hline & KB & 36 & $<\mathrm{LOD}$ & 20.83 & $4.76 \pm 5.08$ \\
\hline \multirow{2}{*}{ Biomarker } & \multirow{2}{*}{ Regency } & \multicolumn{4}{|c|}{ Non-Worker } \\
\hline & & $\mathbf{n}$ & $\operatorname{Min}(\mu \mathrm{g} / \mathrm{g})$ & $\operatorname{Max}(\mu \mathrm{g} / \mathrm{g})$ & $\operatorname{Mean} \pm$ SD $(\mu \mathrm{g} / \mathrm{g})$ \\
\hline \multirow{4}{*}{ Nail } & WG & 15 & 1.21 & 9.77 & $2.89 \pm 2.28$ \\
\hline & MR & 13 & 0.13 & 13.79 & $3.03 \pm 4.04$ \\
\hline & DH & 26 & $<$ LOD & 2.95 & $0.8 \pm 0.77$ \\
\hline & KB & 9 & 0.08 & 4.55 & $1.32 \pm 1.39$ \\
\hline \multirow{4}{*}{ Hair } & WG & 15 & 0.42 & 2.31 & $0.9 \pm 0.45$ \\
\hline & MR & 13 & $<\mathrm{LOD}$ & 23.02 & $2.65 \pm 6,21$ \\
\hline & DH & 26 & 0.1 & 37.04 & $4.21 \pm 7.44$ \\
\hline & KB & 9 & 1.15 & 6.68 & $3.91 \pm 2.29$ \\
\hline
\end{tabular}

Description: $<\mathrm{LOD}=$ Below the detection limit that is $0.00004 \mu \mathrm{g} / \mathrm{g}$

Worker $=$ Worker who use mercury to process the gold

$\mathrm{N} \quad=$ Number of respondents

\subsection{Intoxication Status}

Table 3 shows respondents in all regencies which have mercury intoxicated. In WG Regency, 22 of 35 worker (miner) were diagnosed with mercury intoxication. In the non-miner respondents, only 1 of 15 respondents who diagnosed with mercury intoxication. In MR regency, there were 28 of 34 respondents who were not showing any symptom of mercury intoxication. However, there were 6 miners who experienced mercury intoxication. Miners in MR Regency may have contact with mercury from contaminated river water that also used by miners in upstream regency. In non-miner respondents, there was 1 of 13 respondents who diagnosed with mercury intoxication. In DH Regency, 16 of 30 miners were diagnosed with mercury intoxication, while in non-miner respondents there were only 6 of 26 respondents that diagnosed with mercury intoxication. In KB Regency, 25 of 36 miners were diagnosed with mercury intoxication, while in non-miner respondents there were 5 of 9 who diagnosed with mercury intoxication.

Table 3. Mercury intoxication status

\begin{tabular}{c|c|c|c|c}
\hline & WG & MR & DH & KB \\
\hline ASGM Worker & $62.85 \%(22 / 35)$ & $17.64 \%(6 / 34)$ & $53.33 \%(16 / 30)$ & $69.44 \%(25 / 36)$ \\
\hline Non-Worker & $6.67 \%(1 / 15)$ & $7.69 \%(1 / 13)$ & $23.07 \%(6 / 26)$ & $55.55 \%(5 / 9)$ \\
\hline
\end{tabular}




\subsection{Relationship Between $\mathrm{Hg}$ Concentration in Nails and Hair with Individual Attributes}

Results of the correlation analysis between individual attributes such as BMI (Body Mass Index), duration of stay, and PTWI with $\mathrm{Hg}$ concentration in miner's nails was shown in Figure 2 to Figure 3, while for non-miners was shown in Figure 3 to Figure 4. Figure 2 shows that the concentration of $\mathrm{Hg}$ in the nails of the miners was influenced by duration of stay and PTWI with correlation coefficient (r) of 0.229 and 0.490 respectively, and it is shown positive correlation with level of significance $\alpha=$ $5 \%(\mathrm{p}<0.05)$. Afrifa et al. (2017) suggest that mercury exposure is significantly related to the duration of work as a worker. $\mathrm{Hg}$ concentrations in nails were also influenced by consumption patterns of respondents, where the $\mathrm{Hg}$ concentration found in respondent nails can be obtained and accumulated from daily food intake (such as fish and rice) and from drinking water which consist of river water, ground water, and piping water which has been contaminated by mercury [14]. Ashe (2012) argues that significantly, the factors that influence mercury exposure in human are gender and amounts of fish consumption per month, which in his study also found that someone who consumed more than 12 fishes per month will have unhealthy level of mercury in their body [15]. The results of this study were also supported by Dong et al. (2015) saying that age, gender, percentage of local fish consumption were significantly associated with T-Hg [16].

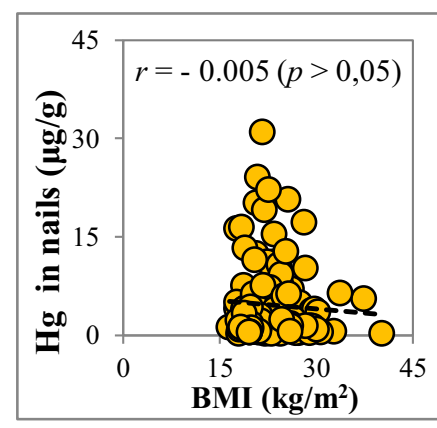

(a)

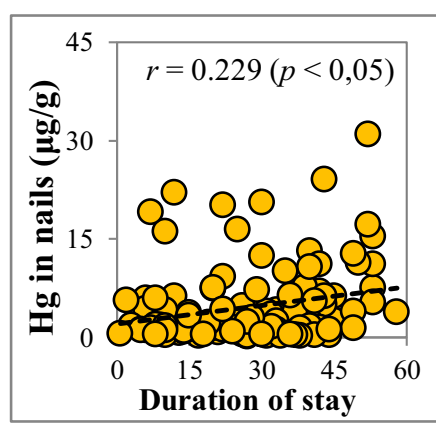

(b)

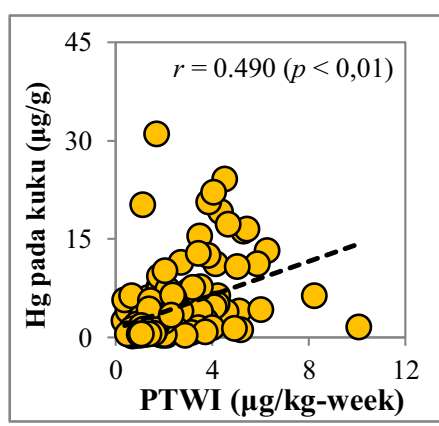

(c)

Fig. 2. Spearman correlation of mercury concentrations in nails of workers with: (a) BMI (Body Mass Index), (b) duration of stay, (c) PTWI

Figure 3 shows the concentration of $\mathrm{Hg}$ in the miner's hair was influenced by duration of stay and PTWI with a sequential correlation coefficient $(r)$ of -
0.216 and -0.207 respectively, where the correlation was significant at $\alpha=5 \%(\mathrm{p}<0.05)$.

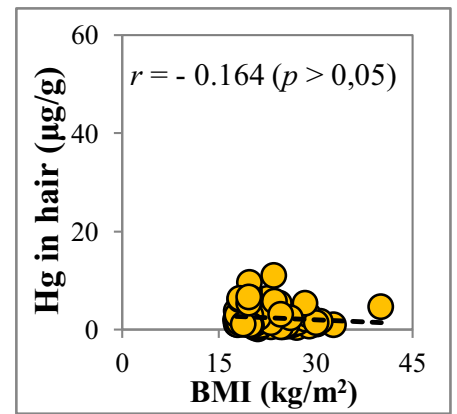

(a)

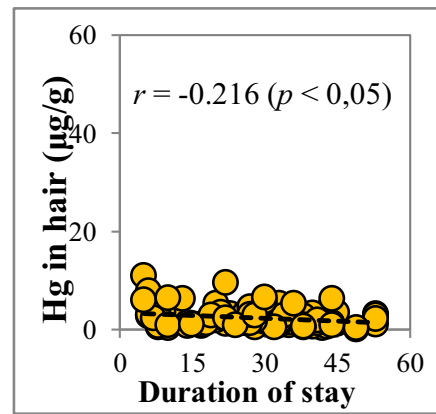

(b)

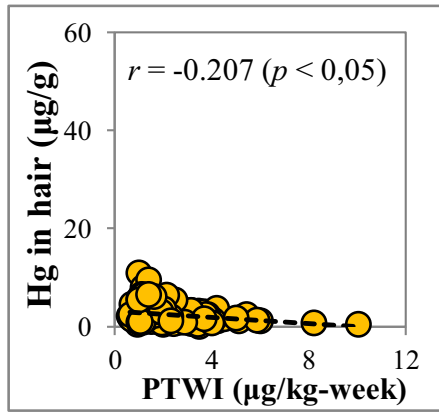

(c)

Fig. 3. Spearman's correlation of mercury concentration in hair of workers with: (a) BMI (Body Mass Index), (b) duration of stay, (c) PTWI

Figure 3 shows that consumption patterns of nonminer respondents through PTWI values were significantly associated with $\mathrm{Hg}$ concentrations in the nails of non-miner respondents. The $\mathrm{Hg}$ concentrations in nails of non-miner respondents were related to weekly consumption patterns (PTWI) with $r=0.406$ and significant at $\alpha=1 \%(\mathrm{p}<0.01)$. The higher consumption of food and water that contaminated with mercury, the greater mercury concentration in nails will occur. Rees et al. said that mercury concentration in nails was significantly correlated with average weekly consumption [17]. 


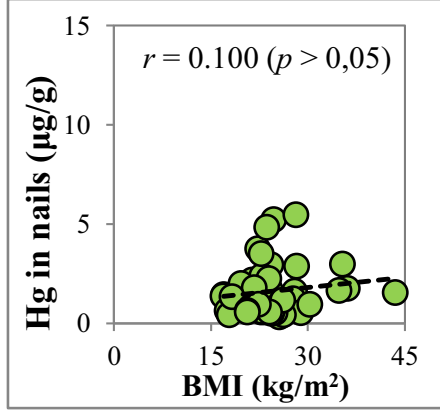

(a)

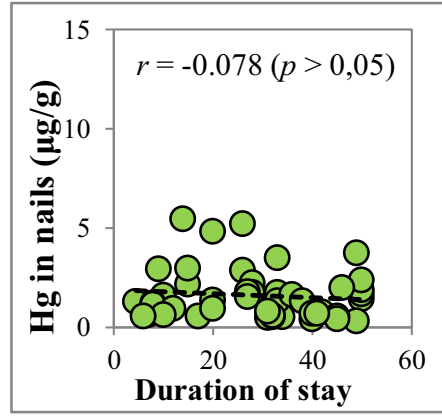

(b)

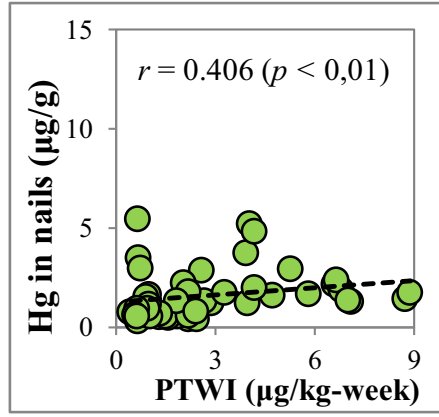

(c)

Figure 3. Spearman correlation of mercury concentration in nails of non-worker respondents with: (a) BMI (Body Mass Index), (b) duration of stay, (c) PTWI

Figure 4 shows that PTWI influence $\mathrm{Hg}$ concentration in non-miner's hair and nail sample. The $\mathrm{Hg}$ concentration in non-miner's hair is significantly correlated with PTWI $(\mathrm{p}<0.05)$ but have a negative correlation with $r=-0.461$. Those were different from the $\mathrm{Hg}$ concentration in the worker's nails which show a positive correlation

PTWI.

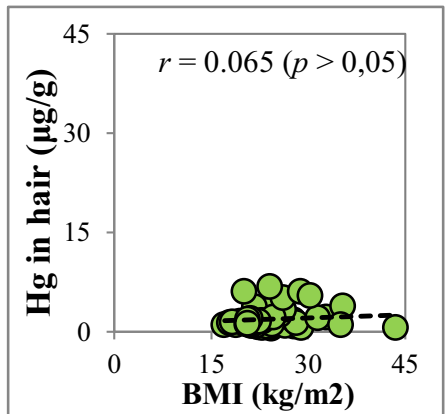

(a)

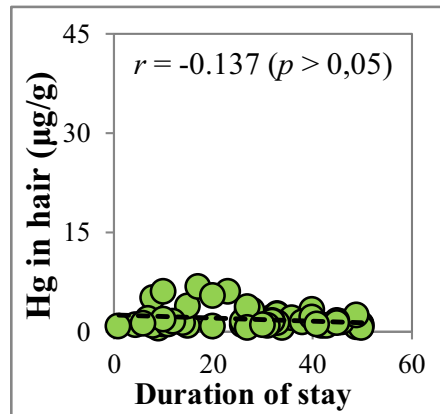

(b)

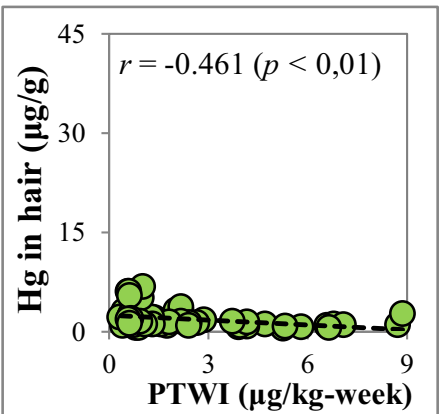

(c)

Fig. 4. Spearman correlation of mercury concentration in hair in non-worker respondents with (a) BMI (Body Mass Index), (b) duration of stay, (c) PTWI

\subsection{Multivariate Regression Analysis}

In worker respondents, independent variables used in this regression analysis were body mass index (BMI) $\left(\mathrm{X}_{1}\right)$, duration of stay $\left(\mathrm{X}_{2}\right)$, and PTWI $\left(\mathrm{X}_{3}\right)$. The regression equation obtained for mercury concentration in miner's nails $\left(\mathrm{Y}_{1}\right)$ is $(1)$ :

$$
Y_{1}=1.646-0.055 X_{1}+0.053 X_{2}+1.103 X_{3}
$$

The $\mathrm{R}^{2}$ value of this equation is 0.150 with a significance of $p<0.01$. This result indicates that there is a simultaneous influence between the independent variables on the dependent variable significantly even though the effect is not too strong because the $\mathrm{R}^{2}$ value is below 0.5 . Of all the independent variables used, the PTWI $\left(\mathrm{X}_{3}\right)$ variable is the most influential and significant variable $(p<0.01)$ on mercury concentrations in nails with a coefficient of 1.103 .

The regression equation obtained for mercury concentration in miner's hair $\left(\mathrm{Y}_{2}\right)(2)$ :

$$
Y_{2}=5.096-0.059 X_{1}-0.023 X_{2}-0.0286 X_{3}
$$

The $\mathrm{R}^{2}$ value that obtained from the results of this analysis is 0.119 with a significance of $p<0.01$. This result indicates that there is a simultaneous influence between the independent variables on the dependent variable significantly even though the effect is not too strong because the $\mathrm{R}^{2}$ value is below 0.5 . However, from each independent variable, the PTWI $\left(\mathrm{X}_{3}\right)$ variable is the most influential variable $(p<0.01)$ on the mercury concentration in the hair with a coefficient value of 0.286 .

In non-worker respondents, independent variable that we used in this regression analysis were BMI $\left(\mathrm{X}_{1}\right)$, duration of stay $\left(\mathrm{X}_{2}\right)$, and PTWI $\left(\mathrm{X}_{3}\right)$. The regression equation obtained for mercury concentration in nonminer's nails $\left(\mathrm{Y}_{3}\right)$ is $(3)$ :

$$
Y_{3}=-0.077+0.062 X_{1}-0.013 X_{2}+0.184 X_{3}
$$

The $\mathrm{R}^{2}$ value that obtained from the results of this analysis is 0.130 with a significance of $p>0.05$. These results indicate that there is no simultaneous influence between the independent variables on the dependent 
variable because the significance value is above 0.05 . Of all the independent variables used, the PTWI $\left(\mathrm{X}_{3}\right)$ variable is the most influential variable $(p<0.05)$ on the mercury concentration in nails with a coefficient value of 0.184 .

The regression equation obtained for mercury concentration in non-miner's hair $\left(\mathrm{Y}_{4}\right)$ is (4):

$$
Y_{4}=3.329-0.013 X_{1}-0.019 X_{2}-0.243 X_{3}
$$

The $\mathrm{R}^{2}$ value that obtained from the results of this analysis is 0.172 with a significance of $p<0.05$. This result indicates that there is a simultaneous influence of the independent variables on the dependent variable because the significance value is below 0.05 . Of all the independent variables used, the PTWI $\left(\mathrm{X}_{3}\right)$ variable is the most influential variable $(\mathrm{p}<0.05)$ on the mercury concentration in nails with a coefficient value of -0.243 .

\section{CONCLUSION}

In the group of miner respondents, the percentage of respondents who had mercury intoxication in WG and KB Regency was higher that MR and DH Regency. This was caused by larger amounts of mercury exposure to workers from amalgam combustion process that carried out in each respondent's houses. PTWI had a significant correlation to mercury concentrations in miner and nonminer's nails and hair, since both groups have relatively similar consumption pattern of mercury-contaminated food. The results of multivariate regression analysis state that PTWI was the variable that most influences mercury concentration in nails and hair.

This study was financially supported by Ministry of Environment and Forestry, Republic of Indonesia. We would like to thank the local government and community of each regency for assisting of data collection.

\section{REFERENCES}

1. S.J. Suprapto, Kelompok Program Penelitian Konservasi-Pusat Sumber Daya Geologi, (2015)

2. D.Z. Herman, Jurnal Geologi Indonesia 1, 31-36 (2006)

3. D.C. Bellinger, K. O'Leary, H. Rainis, Environ Res 147, 159-163 (2016)

4. K. He, Eur. J. Clin. Invest 41, 98-102 (2011)

5. K. Bhupandar, D.P. Mukherjee, Advances in Life Science and Technology 2, 13-24 (2011)

6. G. Saravanabhavan, K. Werry, M. Walker, D. Haines, M. Malowany, C. Khoury, Int Journal of Hyg and Env Health 220, 189-200 (2017)

7. M. Sakamoto, H.M. Chan, J.L. Domingo, R.B. Oliveira, S. Kawakami, K. Murata, Environ. Res 136, 289-294 (2015)

8. Ministry of the Environment Japan, Mercury analysis manual (2004)

9. Badan Standardisasi Nasional, SNI 6989.78:2011 tentang air dan air limbah-bagian 78: cara uji raksa
(Hg) secara spektrofotometri serapan atom (SSA) uap dingin atau mercury analyzer (2011)

10. S. Doering, S.B. O'Reilly, U. Berger, PloS ONE 11, $18(2016)$

11. Badan Standardisasi Nasional (BSN), SNI 7387:2009 tentang batas maksimum cemaran logam berat dalam pangan (2009)

12. WHO, International programme on hemical safety: environmental health criteria 101, methylmercury, http://www.inchem.org/documents/ehc/ehc/ehc101.ht $\mathrm{m} /$ accessed on October $15^{\text {th }} 2018$, (1990)

13. WHO, Guidance for identifying populations at risk from mercury exposure, http://www.who.int/foodsafety/ accessed on December $12^{\text {th }} 2018$ (2008)

14. J. Afrifa, S. Essien-Baidoo, R.K.D. Ephraim, D. Nkrumah, D.O. Dankyira, BMC Public Health 17, 601 (2017)

15. K. Ashe, PloS ONE 7, 6 (2012)

16. Z. Dong, R.C. Jim, E.L. Hatley, A.S.N. Backus, J.P. Shine, J.D. Spengler, L.A. Schaider, Environ Res 136, 155-162 (2015)

17. J.R. Rees, S. Sturup, C. Chen, C. Folt, M.R. Karagas, Journal of Exposure Sci and Env Epid 17, 25-30 (2007) 